\title{
ОСОБЛИВОСТІ ОРГАНІЗАЦІЇ ПРОЦЕСУ РОЗВИТКУ ПРОФЕСІЙНО-ПЕДАГОГІЧНОЇ КОМПЕТЕНТНОСТІ ВИКЛАДАЧІВ ФАХОВИХ ДИСЦИПЛІН ТЕХНІЧНИХ ЗАКЛАДІВ ВИЩОЇ ОСВІТИ
}

\begin{abstract}
Висвітлено особливості організаиії процесу розвитку професійно-педагогічної компетентності викладачів фахових дисциплін технічних закладів вищої освіти в умовах післядипломної педагогічної освіти. Проаналізовано науковопедагогічну літературу, присвячену проблематиці педагогічного експерименту як комплексному методу дослідження, щз використовується для встановлення ефективності і виявлення особливостей проведення певного педагогічного процесу. Окреслено вимоги до програми педагогічного дослідження та його функиії (методологічна, методична, організаційна). Визначено й охарактеризовано етапи програми наукового дослідження: теоретико-методологічний (означення методологічних підходів до аналізу професійно-педагогічної компетентності викладача; з'ясування місия досліджуваної компетентності в системі споріднених педагогічних категорій); структурно-функціональний (обтрунтування структурних компонентів професійно-педагогічної компетентності викладачів технічних закладів вищої освіти, концептуальних основ розвитку ичієї компетентності); організаційно-педагогічний (визначення педагогічних умов розвитку професійно-педагогічної компетентності викладачів технічних закладів вищої освіти; побудова структурно-функиіональної моделі ї̈ розвитку); експериментально-аналітичний (втілення програми експериментального дослідження; аналіз ефективності процесу розвитку досліджуваної компетентності). Означено й описано етапи наукового пошуку експериментальної роботи (підготовчий, експериментальний, контрольно-аналітичний). Зроблено висновок про те, щзо професійно-педагогічна компетентність являє собою складне, інтегративне, професійно-особистісне утворення, яке характеризує сукупність иіннісно-мотиваиійних ресурсів, систему соиіально та професійно важливих якостей, комплекс професійних знань, умінь та навичок, комунікативний досвід і досвід самопізнання, які забезпечують здатність до подальшого саморозвитку. Підкреслено, що саме система післядипломної педагогічної освіти забезпечує розвиток досліджуваної компетентності викладачів технічних закладів вищої освіти за умови їх включення в освітній процес, мотивачійної готовності до набуття нових знань і педагогічно ефективних стратегій організації професійно-педагогічної діяльності.
\end{abstract}

Ключові слова: професійно-педагогічна компетентність, викладач, технічний заклад вищої освіти, процес розвитку професійно-педагогічної компетентності, етапи, педагогічні умови, рівні розвитку, післядипломна педагогічна освіта.

Модернізація вітчизняної вищої освіти на сучасному етапі порушує питання про необхідність посилення уваги до особистісного розвитку всіх суб’єктів освітнього процесу, особливе місце серед яких посідають науково-педагогічні працівники закладів вищої школи. Відповідно до цього сучасній системі освіти необхідні викладачі-професіонали, здатні до системного сприйняття педагогічної дійсності і продуктивної професійної діяльності в ній, до проєктування, конструювання і реалізації освітніх проєктів, готових змінюватись та пристосовуватись до нових потреб ринку праці. Одним із важливих чинників реалізації стійкого механізму підвищення якості кадрового педагогічного персоналу вищої школи $є$ забезпечення розвитку професійно-педагогічної компетентності викладачів, зокрема викладачів фахових дисциплін технічних закладів вищої освіти. Саме тому особливої актуальності сьогодні набуває завдання пошуку нових науково-педагогічних підходів до організації процесу підвищення професійно-педагогічної компетентності викладачів, розгляду одного з яких і присвячене це дослідження.

Аналіз останніх досліджень і публікацій доводить, що проблематика педагогічного експерименту як загальнонаукового методу пізнання, який дає можливість одержати нові знання про причинно-наслідкові відношення між педагогічними чинниками, умовами, процесами завдяки планомірному маніпулюванню однією або кількома дійсними (факторами) і реєстрації відповідних змін у поведінці об'єкта чи системи, що вивчаються [1, с. 174], відображена в різних дослідницьких напрямах і аспектах. Велике значення мають праці таких вітчизняних дослідників, як: Є. Голобородько, Н. Гузій, С. Демченко, В. Кислий, Т. Кожухова, В. Лозова, Г. Ніколаї та інші, а також роботи закордонних авторів, серед яких U. Reips, J. Shaugnessy, E. Zechmeister, J. Zechmeister та інші. Зокрема, Н. Гузій зауважує, що науковий пошук системних якостей та системоутворювальних чинників має базуватись на усвідомленні системності й інтегративності явища професіоналізму педагога, його взаємозв'язку із соціальним середовищем, бути комплексним, ураховувати діяльнісні й особистісні прояви цього новоутворення [2]. Водночас предметом дослідження професійного розвитку науково-педагогічних працівників, зокрема їхньої професійної, професійно-педагогічної компетентності, є роботи Л. Банашко, А. Вербицького, О. Дубасенюк, Т. Колодько, Н. Ничкало, О. Овчарука, Л. Сергеєвої та інших. Методологічні основи, методи організації процесу формування професійно-педагогічної компетентності педагогів знаходимо в роботах Т. Данилової, С. Демченко, В. Єлагіної, Л. Зеленської, Т. Колодько, С. Мурзіної та інших. Однак, незважаючи на те, що кількість спеціальних праць, присвячених проблемі пошуку шляхів професійного розвитку педагогів, а також розгляду особливостей дослідження стану розвитку професійної, педагогічної компетентності в педагогічних, науково-педагогічних працівників постійно зростає, що доводить поглиблення уваги до цього перспективного напряму, питання, пов'язані з висвітленням особливостей організації процесу розвитку професійно-педагогічної компетентності викладачів фахових дисциплін технічних закладів вищої освіти, потребують більшої уваги. 
Мета статті полягає у висвітленні особливостей організації процесу розвитку професійно-педагогічної компетентності викладачів фахових дисциплін технічних закладів вищої освіти.

Складником професійної компетентності науково-педагогічного працівника $є$ професійно-педагогічна компетентність. У своєму дослідженні професійно-педагогічну компетентність викладача технічного закладу вищзӧ освіти ми визначаємо як складне, інтегративне, професійно-особистісне утворення, яке характеризує сукупність ціннісно-мотиваційних ресурсів, систему соціально та професійно важливих якостей і здібностей особистості, комплекс психолого-педагогічних і предметних знань, професійні вміння та навички, комунікативний досвід і досвід самопізнання, які забезпечують здатність до успішної реалізації професійно-педагогічної діяльності та подальшого саморозвитку. Водночас професійно-педагогічна компетентність викладача, як складне особистісно-професійне явище, являє собою готовність до виконання професійно-педагогічних функцій. Ми переконані, що професійно-педагогічна компетентність розвивається у процесі неперервної педагогічної освіти, необхідність якої пояснюється динамічними перетвореннями соціокультурного середовища, яке ставить перед викладачем нові виклики, подолання яких можливе саме завдяки розвитку професійно-педагогічної компетентності.

Зазначимо, що мета нашого педагогічного дослідження полягає в теоретичному та методичному обгрунтуванні сутності професійно-педагогічної компетентності викладачів фахових дисциплін технічних закладів вищої освіти, розробленні й експериментальній перевірці ефективності структурно-функціональної моделі їі розвитку. Як пріоритетний напрям їх професійного становлення педагогічне дослідження розвитку професійно-педагогічної компетентності викладачів фахових дисциплін технічних закладів вищої освіти (далі - ТЗВО) вимагає насамперед обгрунтованої програми.

Як наголошує I. Холховська [4], ця програма має відповідати певним вимогам, серед яких: ясність і точність програми (усі положення чіткі, ясно сформульовані, складники програми продумані відповідно до логіки дослідження); логічна послідовність усіх ланок програми (попереднє формулювання мети і завдань дослідження); гнучкість програми (можливість внесення коректив) [4, с. 53]. Водночас до функцій програми педагогічного дослідження відносимо методологічну (дає змогу визначити проблему (практичну, наукову), для якої здійснюється дослідження, сформулювати цілі і завдання); методичну (надає можливість розроблення загального логічного плану дослідження, визначення методів збору й аналізу інформації, опрацювання процедури дослідження); організаційну (забезпечує контроль за перебігом педагогічного дослідження) [3, с. 28].

Зазначимо, що програма нашого педагогічного дослідження складається 3 таких умовних етапів, як: теоретико-методологічний, структурно-функціональний; організаційно-педагогічний; експериментальноаналітичний (табл. 1).

Програма та зміст педагогічного дослідження

Таблиця 1

\begin{tabular}{|l|l|}
\hline \multicolumn{1}{|c|}{ Назва етапу } & \multicolumn{1}{|c|}{ Зміст експериментальної роботи } \\
\hline Теоретико-методологічний & - визначення методологічних підходів до проблеми розвитку професійно-педагогіч- \\
ної компетентності викладача; & - висвітлення поняття «професійно-педагогічна компетентність» як педагогічного \\
феномену; & - визначення місця досліджуваної компетентності в системі споріднених педагогіч- \\
них категорій; & - аналіз особливостей професійно-педагогічної діяльності викладачів технічних \\
закладів вищої освіти;
\end{tabular}


Реалізація мети дослідження та підтвердження загальної і часткових гіпотез передбачали певні етапи наукового пошуку експериментальної роботи, до яких нами віднесено підготовчий, експериментальний, контрольноаналітичний. Зупинимося докладніше на характеристиці кожного з означених етапів експериментальної роботи.

Підготовчий етап був спрямований на виявлення ступеня розробленості проблеми дослідження в науковопедагогічній літературі й освітній практиці; обгрунтування ключових понять дослідження (компетентність, компетенція, професійна компетентність, педагогічна компетентність, професійно-педагогічна компетентність); розгляд методологічних основ наукового пошуку; встановлення співвідношення поняття «професійнопедагогічна компетентність» зі спорідненими педагогічними категоріями («професійно-педагогічна культура», «педагогічна майстерність», «педагогічна кваліфікація», «педагогічний професіоналізм», «професійна готовність»); обгрунтування сутності та структурних компонентів професійно-педагогічної компетентності викладачів фахових дисциплін технічних закладів вищої освіти (мотиваційно-ціннісний, пізнавально-інтелектуальний, функціонально-технологічний, соціально-комунікативний та рефлексивно-регулятивний); обгрунтування теоретичних основ розвитку професійно-педагогічної компетентності викладачів фахових дисциплін технічних 3ВО у процесі післядипломної педагогічної освіти. Аналіз практики підвищення кваліфікації викладачів технічних закладів вищої освіти дав змогу виявити важливі потенційні можливості змісту післядипломної професійно-педагогічної підготовки щодо розвитку професійно-педагогічної компетентності викладачів технічних 3ВО. Водночас контекст цього етапу передбачав виокремлення учасників дослідно-експериментальної роботи; конкретизування завдань діяльності відповідно до мети; проведення форм методичної роботи 3 підготовки викладачів-лекторів до безпосередньої реалізації завдань дослідно-експериментальної роботи.

Експериментальний етап грунтувався на розробленні програми дослідно-експериментальної роботи; опрацюванні діагностичних методик та інструментарію експериментального дослідження. Водночас визначались критерії та показники розвитку професійно-педагогічної компетентності викладачів фахових дисциплін технічних закладів вищої освіти відповідно до структурних компонентів досліджуваної компетентності (табл. 2); проводився констатувальний етап експерименту з метою виявлення вихідного рівня розвитку професійно-педагогічної компетентності викладачів фахових дисциплін.

\section{Критерії розвитку професійно-педагогічної компетентності викладачів фахових дисциплін технічних 3 BO}

\begin{tabular}{|l|l|}
\hline \multicolumn{1}{|c|}{ Критерії розвитку } & \multicolumn{1}{c|}{$\begin{array}{c}\text { Структурні компоненти } \\
\text { професійно-педагогічної компетентності }\end{array}$} \\
\hline інтегративно-теоретичний & пізнавально-інтелектуальний \\
\hline ціннісно-мотиваційний & мотиваційно-ціннісний \\
\hline функціонально-технологічний & діяльнісно-операційний \\
\hline особистісно-комунікаційний & соціально-комунікативний \\
\hline оцінно-рефлексивний & рефлексивно-регулятивний \\
\hline
\end{tabular}

Зокрема, для початкової діагностики в поєднанні використовувались адаптовані до цілей дослідження такі методики, технології та тести: авторські анкети; «Професійно-значущі якості учителя» (за О. Галіцан); «Визначення рівня ціннісних орієнтацій» (за М. Рокічем); «Діагностика рівня професійної спрямованості» (за Т. Дубовицькою); «Мотивація професійної діяльності» (за А. Реаном); «Методика діагностики творчої активності» (за Б. Алішевим, М. Рожковим); «Оцінка здатності до саморозвитку і самоосвіти» (за В. Андрєєвою); методики на визначення комунікативних умінь (за В. Ряховським); «Діагностика рівня рефлексивності» (за А. Карповою); «Самооцінка особистості» (за М. Пришак); «Дослідження вольової саморегуляції» (за С. Слідман); «Самоаналіз та самовизначення» (за С. Вершловським); «Самооцінка особистості» (за В. Семиченко); спостереження.

Водночас важливим у межах даного етапу було теоретичне обгрунтування педагогічних умов, як-от: неперервність процесу розвитку професійно-педагогічної компетентності викладачів фахових дисциплін технічних закладів вищої освіти; формування професійної мотивації до самоосвіти, саморозвитку і самореалізації у професійно-педагогічній діяльності в умовах підвищення кваліфікації; наповнення змісту післядипломної професійної підготовки викладачів технічних закладів вищої освіти розвивальними технологіями професійної освіти; спонукання викладачів фахових дисциплін до педагогічної рефлексії у професійно-педагогічній діяльності з метою побудови траєкторії власного професійного розвитку. Розроблена структурно-функціональна модель розвитку професійно-педагогічної компетентності викладачів фахових дисциплін технічних ЗВО об’єднувала програмно-цільовий, теоретико-методологічний, діяльнісно-технологічний, контрольнорезультативний компоненти (блоки).

Відповідно до програми формувального етапу як складової частини експериментального етапу дослідження здійснювались упровадження й апробація розробленої моделі; реалізовувались виокремлені педа- 
гогічні умови; опрацьовувалось методичне забезпечення. Так само впроваджувалась професійна програма підвищення кваліфікації науково-педагогічних працівників «Розвиток професійно-педагогічної компетентності викладача закладу вищої освіти», яка містила п’ять послідовних навчальних блоків: «Сучасні аспекти розвитку педагогіки XXI століття», «Інформаційні комп’ютерні педагогічні технології в освіті», «Методичні особливості викладання дисциплін у закладі вищої освіти», «Психолого-педагогічні основи діяльності викладача закладу вищої освіти», «Юридично-правові аспекти педагогічної діяльності викладача закладу вищої освіти».

Необхідно зазначити, що з метою підготовки і проведення експериментального дослідження викладачілектори курсів підвищення кваліфікації були ознайомлені з авторською моделлю та змістом професійної програми «Розвиток професійно-педагогічної компетентності викладача закладу вищої освіти». Важливо підкреслити, що дотримання викладачами, залученими до експерименту, виокремлених педагогічних умов сприяло розвитку компонентів професійно-педагогічної компетентності викладачів фахових дисциплін технічних 3ВО, їх активному неперервному професійному розвитку.

Водночас проведення формувального етапу експерименту передбачало проведення підсумкової діагностики, спрямованої на з'ясування рівнів (адаптивний, нормативний, продуктивний, самоорганізований) розвитку професійно-педагогічної компетентності викладачів фахових дисциплін технічних закладів вищої освіти.

Контрольно-аналітичний етап був спрямований на проведення контрольного діагностування рівня розвитку досліджуваної компетентності викладачів фахових дисциплін за визначеними на попередньому етапі критеріями і показниками; порівняння і співвідношення результатів констатувального і формувального етапів; системне оцінювання ефективності моделі розвитку професійно-педагогічної компетентності викладачів фахових дисциплін технічних закладів вищої освіти.

Висновки. Здійснене висвітлення особливостей організації процесу розвитку професійно-педагогічної компетентності викладачів фахових дисциплін технічних закладів вищої освіти дозволяє зазначити, що: досліджувана компетентність являє собою гармонійний сплав загальнокультурної, психолого-педагогічної, предметної і методичної підготовки, практичного досвіду, професійно важливих особистісних якостей і цінностей, які забезпечують успішність професійно-педагогічної діяльності; система післядипломної педагогічної освіти забезпечує розвиток професійно-педагогічної компетентності викладачів технічних ЗВО за умови їх включення в освітній процес, мотиваційної готовності до набуття нових знань і педагогічно ефективних стратегій організації професійно-педагогічної діяльності; програма педагогічного дослідження складається з етапів (теоретико-методологічний, структурно-функціональний; організаційно-педагогічний; експериментально-аналітичний); етапами наукового пошуку експериментальної роботи стали підготовчий, експериментальний, контрольно-аналітичний.

Перспективи подальших досліджень полягають у висвітленні аналізу ефективності науково-методичної системи розвитку професійно-педагогічної компетентності викладачів фахових дисциплін технічних закладів вищої освіти.

\section{Використана література:}

1. Гончаренко С. Педагогічні дослідження : методологічні поради молодим науковцям. Київ ; Вінниця : ДОВ «Вінниця», 2008. $278 \mathrm{c}$.

2. Гузій Н. Категорія професіоналізму в теорії і практиці підготовки майбутнього педагога : дис. ... докт. пед. наук: 13.00.04. Київ, 2007. 475 с.

3. Кислий В. Організація наукових досліджень : навчальний посібник. Суми : Університетська книга, 2011. 224 с.

4. Професійно-педагогічна компетентність викладача вищого навчального закладу : навчальний посібник / за ред. І. Холховської. Вінниця : ТОВ «Нілан Лтд», 2017. 144 с.

\section{References:}

1. Honcharenko, S. U. (2008). Pedahohichni doslidzhennia: Metodolohichni porady molodym naukovtsiam [Pedagogical research: Methodological advice for young scientists]. Kyiv - Vinnytsia: DOV «Vinnytsia» [in Ukrainian].

2. Huzii, N. V. (2007). Katehoriia profesionalizmu v teorii i praktytsi pidhotovky maibutnoho pedahoha [Category of professionalism in the theory and practice of training future teachers]. Doctor's thesis. Kyiv [in Ukrainian].

3. Kyslyi, V. M. (2011). Orhanizatsiia naukovykh doslidzhen: navchalnyi posibnyk [Organization of scientific research: a textbook]. Sumy: University book [in Ukrainian].

4. Kholkhovska, I. L. (Ed.).(2017). Profesiino-pedahohichna kompetentnist vykladacha vyshchoho navchalnoho zakladu: navchalnyi posibnyk [Professional-pedagogical competency of a teacher of higher education: a textbook]. Vinnytsia: TOV «Nilan LTD» [in Ukrainian].

Horokhivska T. M. Organizing the development of professional-pedagogical competency in lecturers of professional disciplines from technical universities

The article describes the organization of developing professional-pedagogical competency in lecturers of professional disciplines from technical universities in the context of postgraduate teacher education. It analyzes relevant scientific-pedagogical literature on the problems of the pedagogical experiment as a complex research method establishing the effectiveness and identifying the features of a particular pedagogical process. Also, the article isolates the requirements to the pedagogical research programme and its functions (methodological, methodical, organizational). It determines and describes the stages of the programme: theoretical and methodological (identifying methodological approaches to analyzing lecturers' profession- 
al-pedagogical competency; specifying the role of this competency in the system of related pedagogical categories); structural and functional (justifying structural components of professional-pedagogical competency of lecturers from technical universities, conceptual principles of developing this competency); organizational and pedagogical (determining pedagogical conditions for developing professional-pedagogical competency in lecturers from technical universities; designing a structural-and-functional model of its development); experimental and analytical (implementing the experimental research programme; analyzing development levels of professional-pedagogical competency). Besides, the article defines and describes the stages of experimental work (preparatory, experimental, controlling and analytical). It concludes that professional-pedagogical competency is a complex, integrative, professional-personal quality, which characterizes a set of axiological and motivational resources, a system of socially and professionally important qualities, a range of professional knowledge, skills, communicative and cognitive experience, which motivate lecturers towards further self-development. Finally, the article indicates that the system of postgraduate teacher education ensures the development of professional-personal competency in lecturers from technical universities under the following conditions: lecturers act as the actors in the educational process; they are ready to acquire new knowledge and pedagogically effective strategies for organizing professional-pedagogical activities.

Key words: professional-pedagogical competency, lecturer, technical university, development of professional-pedagogical competency, stages, pedagogical conditions, development levels, postgraduate teacher education.

\author{
УДК 37.017.7:373.8 \\ DOI https://doi.org/10.31392/NPU-nc.series5.2020.76.11
}

Грузевич Т. Ю.

\title{
РЕТРОСПЕКТИВНИЙ АНАЛІЗ ГРОМАДЯНСЬКОГО ВИХОВАННЯ ОСОБИСТОСТІ В ЗАРУБІЖНІЙ ФІЛОСОФСЬКО-ПЕДАГОГІЧНІЙ НАУЦІ
}

Здійснено ретроспективний наліз проблеми громадянського виховання особистості в зарубіжній філософсько-педагогічній науці. Автор звертає увагу на те, що ідея громадянськості в різні часи посідала особливе місие не тільки в духовному житті суспільства, а й в усіх значущих сферах його діяльності - ідеологї, політиці, культурі, військовій сфері.

Питання громадянського виховання було одним із фундаментальних питань в історії філософії $і$ педагогіки. Ще стародавні філософи порушували питання, пов'язані із громадянськими якостями, як моральними та соиіально-політичними. В античні часи поняття «громадянське суспільство» $i$ «держава» були взаємозамінними.

Для громадянського виховання доби Середньовіччя характерні: увага до людської душі; пріоритет віри над знаннями, наукою; виховання відповідальності за допомогою вивчення текстів Святого Письма; нерозривний зв'язок громадянського виховання з моральним становленням особистості.

Гуманісти епохи Відродження обстоювали необхідність та можливість відродження ідеї громадянського виховання.

Вияв особливого інтересу до ідеї громадянського суспільства припадає на ХVII століття, коли з'являється теорія громадянського суспільства Дж. Локка.

Цікавими в контексті нашого дослідження є думки про розвиток громадянського виховання із творчого доробку педагогів епох Просвітництва та Нового часу.

Наприкінці XIX - на початку XX століття в педагогіиі закордонних розвинутих країн виникла низка реформаторських течій, які базувалися на громадянському, національно-патріотичному вихованні і культивували любов до свого народу, його мови, держави та їі інститутів. Широко вживався термін «виховання громадянина», який базувався на підвалинах виховання людини - патріота своєї Вітчизни.

Результати ретроспективного аналізу проблеми громадянського виховання особистості дають підстави автору стверджувати, щуо ідея громадянського виховання пройшла складний шлях еволюиійного розвитку від ствердження людством думки про необхідність збереження власної домівки, родини, культури до свідомих, прогресивних пошуків педагогів, популяризації та практичного застосування громадянської культури.

Аналіз окресленого питання в закордонній філософсько-педагогічній науйі дає підстави стверджувати, щчо в різні історичні періоди розвитку людства тлумачення сутності громадянського виховання демонструє залежність від рівня суспільно-політичного розвитку і тих прочесів, щзо відбувалися.

Ключові слова: громадянське виховання, держава, громадянськість, особистість, суспільство, філософи, педагоги.

Виховання громадянина - одне з найважливіших завдань, яке стоїть перед сучасним українським суспільством. Історія теоретичних досліджень громадянських цінностей, громадянської самосвідомості налічує багато століть. За сучасних умов загострення зовнішньополітичного становища України, коли українському народові зі зброєю в руках доводиться відстоювати суверенітет і незалежність нашої держави, давати відсіч російському агресору на сході країни, предметом уваги є реформування національної системи освіти, іiі інтеграції в європейський культурний простір для виховання свідомих громадян. Отже, постала потреба здійснити ретроспективний аналіз проблеми громадянського виховання молодого покоління в різні історичні періоди розвитку людства. Критично проаналізуємо ідеї громадянського виховання в різні часи i матимемо можливість їх творчого використання в сучасній педагогічній практиці. 